\title{
Kolizyjnoprawna problematyka skuteczności przelewu wierzytelności wobec osób trzecich Closa do wyroku Trybunału Sprawiedliwości Unii Europejskiej z dnia 9 października 2019 r. w sprawie BGL BNP Paribas SA c/a TeamBank AG Nürnberg (C-548/18)
}

\begin{abstract}
The question of the law applicable to the third-party effects of assignments of claims is widely discussed in the doctrinal debates. In common opinion, the existing European conflict-of-laws regulations do not provide for a rule governing this issue. In the case BGL BNP Paribas SA v. TeamBank AG Nürnberg (C-548/18), the Court of Justice of the European Union confirmed this gape of the Rome I Regulation.

The gloss presents the justification of the European Union Court's judgment, the reasons for the lack of the uniform conflict-of-laws regulation, and the consequences of this state. It also analyses briefly the European Commission's proposal for the EU Regulation concerning the law applicable to the third-party effects of assignments of claims (COM(2018) 96 final), as a response to this situation. Finally, it examines the appropriate conflict-of-laws rules for proprietary effects of assignments of claims (the law of the assignor's habitual residence and the law of the assigned claim).
\end{abstract}

Keywords: the conflict of laws, the assignments, the third-party effects of assignment, the law applicable to the proprietary effects of assignments, the contractual obligations, Rome I Regulation

\footnotetext{
a) Dr hab., prof. UŚ, Uniwersytet Śląski w Katowicach.
} 


\section{Uwagi ogólne}

Długo przyszło czekać na przesądzenie kwestii na pierwszy rzut oka oczywistej. Trybunał Sprawiedliwości Unii Europejskiej dopiero po dziesięciu latach od przyjęcia rozporządzenia Rzym $\mathrm{I}^{1}$ miał okazję do wydania wyroku, w którym orzekł: „artykuł 14 [tego aktu] należy interpretować w ten sposób, że nie wskazuje on - ani bezpośrednio, ani poprzez analogię - prawa właściwego dla kwestii skuteczności wobec osób trzecich przelewu wierzytelności w przypadku wielokrotnego przelewu wierzytelności dokonywanego przez tego samego wierzyciela na rzecz kolejnych cesjonariuszy". Stwierdzenie to nie powinno budzić większych kontrowersji, zważywszy na losy projektu rozporządzenia ${ }^{2}$, który w pierwotnej wersji przewidywał, że skuteczność przelewu wierzytelności wobec osób trzecich podlegać powinna prawu państwa, w którym cedent ma miejsce zwykłego pobytu $\mathrm{w}$ momencie przelewu lub przeniesienia, a na etapie uzgodnień został pozbawiony regulacji odnoszącej się do poruszanej tu kwestii. Co więcej, o istnieniu nierozwiązanego w rozporządzeniu Rzym I problemu normy kolizyjnej dotyczącej skuteczności cesji wobec osób trzecich zdawano sobie sprawę, przyjmując ostateczną wersję tego aktu, gdyż zamiast właściwej regulacji, w art. 27 ust. 2 wprowadzono mechanizm monitorujący, zakładający - w razie konieczności — podjęcie działań zmierzających do usunięcia niekorzystnych skutków świadomego pominięcia spornego unormowania. We wskazanym przepisie Komisja Europejska została zobowiązana do przedłożenia do dnia 17 czerwca $2010 \mathrm{r}$. Parlamentowi Europejskiemu, Radzie i Europejskiemu Komitetowi Ekonomiczno-Społecznemu sprawozdania na temat skuteczności przelewu wierzytelności (wobec osób trzecich) oraz pierwszeństwa przenoszonej wierzytelności przed prawami innych osób. Co prawda, Komisja Europejska terminu tego nie dochowała, ale ostatecznie, w 2012 r., na jej zlecenie British Institute of International and Comparative Law opracował raport, który stał się przyczynkiem do sprawozdania dla Parlamentu Europejskiego, Rady i Europejskiego Komitetu Ekonomiczno-Społecznego zarówno na temat prawnokolizyjnych skutków przelewu lub subrogacji wierzytelności dla osób trzecich, jak i pierwszeństwa przenoszonej wierzytelności przed prawami innych podmiotów. Ono z kolei otwarło debatę

${ }^{1}$ Rozporządzenie (WE) nr 593/2008 Parlamentu Europejskiego i Rady z dnia 17 czerwca 2008 r. dotyczące prawa właściwego dla zobowiązań umownych (Rzym I). Dz.Urz. UE L nr 177 z dnia 4.07.2008, s. 6-16.

${ }^{2}$ Por. art. 13 ust. 3 projektu zawartego we wniosku Komisji dotyczacego rozporzadzenia Parlamentu Europejskiego i Rady w sprawie prawa właściwego dla zobowiązań umownych (Rzym I). COM(2005) 650 wersja ostateczna. 
i prace nad projektem nowej unijnej regulacji ${ }^{3}$, poświęconej kolizyjnym aspektom skuteczności cesji względem osób trzecich ${ }^{4}$.

Równolegle z tymi pracami w doktrynie trwała dyskusja o zakresie art. 14 rozporządzenia Rzym I, w tym możliwego jego stosowania do wskazywania prawa właściwego dla skuteczności przelewu wierzytelności wobec osób trzecich. Co prawda, większość przedstawicieli doktryny uznawała, że rozporządzenie Rzym I nie daje podstaw do wyznaczenia w tym zakresie miarodajnego statutu ${ }^{5}$, jednakże pogląd przeciwny także znajdował swoich zwolenników ${ }^{6}$.

${ }^{3}$ Projekt rozporządzenia w sprawie prawa właściwego dla skutków przelewu wierzytelności wobec osób trzecich został opracowany i przedstawiony przez Komisję Europejską w marcu 2018 r. $\operatorname{COM}(2018) 96$ wersja ostateczna.

${ }^{4}$ Projekt rozporządzenia został omówiony szczegółowo przez W. Kurowskiego. W. Kurowski: Kolizyjnoprawna problematyka skuteczności przelewu wierzytelności wobec osób trzecich - projekt rozporzadzenia Parlamentu Europejskiego i Rady $w$ sprawie prawa wtaściwego dla skutków przelewu wierzytelności wobec osób trzecich (COM(2018) 96 final). „Problemy Prawa Prywatnego Międzynarodowego” 2019, T. 25, s. 67-90.

${ }^{5}$ S. Leible, M. Lehmann: Die Verordnung über das auf vertragliche Schuldverhältnisse anzuwendende Recht (,Rom I”). „Recht der Internationalen Wirtschaft” 2008, H. 8, s. 541; F.J. Garcimartín Alférez: Assignment of claims in the Rome I Regulation: Article 14. In: Rome I Regulation. The Law Applicable to Contractual Obligations in Europe. Eds. F. Ferrari, S. Leible. Munich 2009, s. 234-235; M.P. Zachariasiewicz: Zmiany w unormowaniu cesji wierzytelności (od artykułu 12 konwencji rzymskiej do artykutu 14 rozporzadzenia Rzym I). „Problemy Prawa Prywatnego Międzynarodowego" 2010, T. 6, s. 144-154; T.C. Hartley: Choice of law regarding the voluntary assignment of contractual obligations under the Rome I Regulation. „International and Comparative Law Quaterly" 2011, no. 1, s. 46-56; A. Wowerka: Prawo właściwe dla transakcji faktoringowych. „Problemy Prawa Prywatnego Międzynarodowego” 2009, T. 4, s. 157; Idem: Przelew wierzytelności w świetle rozporzqdzenia Rzym I. „Problemy Prawa Prywatnego Międzynarodowego" 2011, T. 8, s. 44-53; W. Kurowski: Nowe kolizyjnoprawne unormowanie podmiotowych zmian stosunku zobowiqzaniowego na tle rozporzadzenia „Rzym I” i polskiej ustawy - Prawo prywatne międzynarodowe $z 2011 \mathrm{r}$. W: Wspótczesne wyzwania prawa prywatnego międzynarodowego. Red. J. Poczobut. Warszawa 2013, s. 146-147; Idem: Prawo właściwe do oceny skuteczności przelewu wierzytelności wobec osób trzecich. W: Znad granicy ponad granicami. Księga dedykowana Profesorowi Dieterowi Martiny. Red. M. Krzy muski, M. Margoński. Warszawa 2014, s. 164.

${ }^{6}$ Zdanie odmienne w tym zakresie wyrazili m.in.: A. Flessner, H.L.E. Verhagen: Assignment in European Private International Law. Claims as property and the European Commission's 'Rome I Proposal'. Munich 2006, s. 24-26; H.L.E. Verhagen, S. van Dongen: Cross-border assignments under Rome I. „Journal of Private International Law" 2010, no. 1, s. 1-21; A. Flessner: Choice of Law in International Property Law - New Encouragement from Europe. In: Party Autonomy in International Property Law. Eds. R. Westrik, J. van der Weide. Munich 2011, s. 11-40; M. Czepelak: Międzynarodowe prawo zobowiazań Unii Europejskiej. Komentarz do rozporzadzeń rzymskich. Warszawa 2012, s. 422-426. 
Właśnie z tego powodu dobrze się stało, że Trybunał Sprawiedliwości Unii Europejskiej miał okazję do wypowiedzenia się w tej spornej kwestii i przesądzenia nader istotnego problemu prawnego.

\section{Pytania prejudycjalne}

Sprawa, która stała się przyczynkiem do wydania przez Trybunał Sprawiedliwości Unii Europejskiej komentowanego orzeczenia nie była szczególnie skomplikowana. Zamieszkała w Niemczech obywatelka Luksemburga zawarła z dwoma bankami umowy pożyczki, przy czym pierwsza podlegała prawu niemieckiemu, a druga — luksemburskiemu. Na ich zabezpieczenie dokonała przelewu tych samych wierzytelności z tytułu wynagrodzenia za pracę, zawiadamiając formalnie swojego pracodawcę jedynie o drugim z nich. W związku z ogłoszeniem przez dłużniczkę upadłości i zgłoszeniem się do syndyka obu banków - wierzycieli z umów pożyczki - powstał spór, komu przysługuje prawo do ściągniętych od luksemburskiego pracodawcy sum, będących zapłatą za świadczona pracę, a zatem - który przelew wierzytelności o wynagrodzenie za pracę jest skuteczny względem osób trzecich (albo - ujmując problem jeszcze inaczej - któremu z konkurujących podmiotów należy przyznać pierwszeństwo do wierzytelności będącej przedmiotem obu cesji). Pierwszy z banków powoływał się na fakt skutecznego nabycia wierzytelności od osoby będącej wierzycielem, kwestionując uprawnienia drugiej instytucji finansowej, dokonującej później czynności prawnej z już nieuprawnionym. $\mathrm{Z}$ kolei ten drugi bank kwestionował skuteczność (wobec osób trzecich) pierwszego przelewu wierzytelności w związku z brakiem zawiadomienia dłużnika o dokonaniu cesji, powołując się na art. 1690 ust. 1 kodeksu cywilnego Luksemburga, zgodnie z którym przelew wierzytelności wywiera skutki wobec osób trzecich jedynie wówczas, gdy dłużnik został o nim zawiadomiony. Warto podkreślić, że istota problemu nie wiązała się z samym postępowaniem upadłościowym, jego podstawą prawną czy też skutecznością przelewów wierzytelności względem masy upadłości. Tym razem przepisy nieobowiąującego już rozporządzenia Rady (WE) nr 1346/2000 z dnia 29 maja 2000 r. w sprawie postępowania upadłościowego ${ }^{7}$ nie budziły wątpliwości.

${ }^{7}$ Rozporzadzenie Rady (WE) nr 1346/2000 z dnia 29 maja 2000 r. w sprawie postępowania upadłościowego. Dz.Urz. UE L nr 160 z dnia 30.06.2000, s. 191—208, obecnie nie obowiązuje. 
Na tle tak zarysowanego stanu faktycznego Saarländisches Oberlandesgericht zwrócił się do Trybunał Sprawiedliwości Unii Europejskiej z następującymi pytaniami prejudycjalnymi:

1. Czy art. 14 rozporządzenia Rzym I ma zastosowanie do wielokrotnego przelewu wobec osób trzecich?

2. W razie udzielenia odpowiedzi twierdzacej na pytanie pierwsze: Jakiemu prawu podlegaja $\mathrm{w}$ takim przypadku skutki przelewu wobec osób trzecich?

3. W razie udzielenia odpowiedzi przeczącej na pytanie pierwsze: Czy przepis ten znajduje zastosowanie przez analogię?

4. W razie udzielenia odpowiedzi twierdzacej na pytanie trzecie: Jakiemu prawu podlegaja w takim przypadku skutki wobec osób trzecich? Analiza wskazanych pytań prejudycjalnych skłania już na wstępie do wniosku, że nie zostały one postawione zbyt szczęśliwie. Trybunał Sprawiedliwości Unii Europejskiej dał temu wyraz w swoim orzeczeniu, a w szczególności - w jego uzasadnieniu. Co prawda, sądowi meriti chodziło jedynie o udzielenie odpowiedzi na pytanie, czy art. 14 rozporzadzenia Rzym I wskazuje wprost bądź per analogiam prawo właściwe dla skuteczności cesji wobec osób trzecich w przypadku wielokrotnego przelewu danej wierzytelności dokonywanego przez tego samego wierzyciela na rzecz innych podmiotów ${ }^{8}$, jednakże należy pamiętać, że wskazany problem szczególny należy do szerszego zagadnienia - skuteczności cesji wierzytelności wobec osób trzecich i jemu powinno zostać poświęcone pytanie prejudycjalne Saarländisches Oberlandesgericht. Nie budzi bowiem wątpliwości, że w podobnej - z punktu widzenia kolizyjnego - sytuacji znajdują się inne podmioty, które mają interes w tym, by ustalić, komu będaca przedmiotem przelewu wierzytelność przysługuje. Pomijając dłużnika, który - co prawda - nie jest stroną umowy przelewu i w związku z tym mógłby być określany jako „osoba trzecia”, jednak jego szczególna sytuacja (odrębnie uregulowana) każe wyłączyć go z omawianego zbioru, przeniesienie wierzytelności w bezpośredni sposób wpływa na sytuację prawną:

a) wierzycieli cedenta;

b) wierzycieli cesjonariusza;

c) kolejnych cesjonariuszy, jeżeli dana wierzytelność jest przedmiotem wielokrotnego, sukcesywnego przelewu' ${ }^{9}$;

8 Tak też wprost TSUE w uzasadnieniu wyroku C-548/18, pkt 23.

${ }^{9} \mathrm{~W}$ przypadku wielokrotnego, sukcesywnego przelewu tej samej wierzytelności jej nabywca, będący stroną pierwszej umowy przelewu, staje się zbywcą w następnej umowie. Dla kolejnego nabywcy istotna staje się odpowiedź na pytanie, czy zbywcy wierzytelności przysługiwało dane prawo podmiotowe przy dokonywaniu tej następnej czynności prawnej, albo inaczej - czy w drodze tej czynności prawnej nabędzie wierzytelność będaccą przedmiotem przelewu. 
d) innych cesjonariuszy, jeżeli dana wierzytelność jest przedmiotem przelewów dokonywanych przez tego samego cedenta (tak jak to miało miejsce w przypadku stanowiącym podstawę pytań prejudycjalnych ${ }^{10}$;

e) syndyka masy upadłości cedenta (innego podmiotu pełniącego zbliżoną do niego funkcję w odniesieniu do majątku zbywcy wierzytelności); trzeba bowiem pamiętać, że przelew wierzytelności uszczupla majątek cedenta (a zatem modyfikuje skład masy upadłości) ${ }^{11}$, a merytorycznoprawne regulacje dotyczace upadłości przewidują z reguły możliwość uznania za bezskuteczne rozporzadzenia prawami podmiotowymi, dokonane w oznaczonym czasie przed ogłoszeniem upadłości.

Dla wskazanych wyżej osób istotna jest odpowiedź na pytanie, komu dana wierzytelność przysługuje, a zatem czy do przeniesienia tego prawa podmiotowego doszło, a jeśli tak — to w jakiej chwili. Inaczej można na to zagadnienie spojrzeć jako na konkurencję podmiotów do uzyskania możliwości zaspokojenia $\mathrm{z}$ wierzytelności będącej przedmiotem cesji i prawne usankcjonowanie pierwszeństwa jednego z nich względem pozostałych. W normalnym biegu rzeczy z chwila przeniesienia wierzytelność zasila majątek cesjonariusza, uszczuplając zasoby cedenta. Uprawnienie do prowadzenia egzekucji z tej wierzytelności traca zatem wierzyciele zbywcy, a ten ostatni - możliwość dokonywania jej cesji na rzecz innych podmiotów. Jeżeli dokonałby on kolejnej czynności rozporządzającej odnoszącej się do tej samej wierzytelności, to do jej przeniesienia nie powinno dojść, gdyż w majątku cedenta nie ma składnika, którego czynność dotyczyła. Jednocześnie z chwilą pierwszego przelewu uprawnienie do prowadzenia egzekucji z przeniesionej wierzytelności uzyskują wierzyciele cesjonariusza; on też może dokonywać kolejnych cesji na rzecz dalszych osób trzecich. Jednakże ten prosty schemat bywa przez prawodawców modyfikowany. Wynika to z faktu, że wierzytelność, będacca przedmiotem przelewu, nie ma charakteru materialnego, a zatem ustalenie chwili jej przeniesienia staje się dla podmiotów nieuczestniczących $\mathrm{w}$ transakcji (a zatem wszystkich, z wyjątkiem stron umowy cesji) szczególnie utrudnione. Dlatego też prawodawcy reguluja niekiedy kwestię skuteczności przelewu wobec tych podmiotów w oderwaniu od

${ }^{10} \mathrm{~W}$ przypadku przelewów tej samej wierzytelności na rzecz różnych podmiotów powstaje spór, m.in. komu dana wierzytelność przysługuje. Sytuacja taka może zaistnieć np. wówczas, gdy cedent - przekonany o nieważności lub nieskuteczności poprzedniej umowy przelewu - dokonuje kolejnej czynności prawnej w odniesieniu do tej samej wierzytelności z inną osoba, albo też gdy do zawarcia kolejnej umowy z innym podmiotem dochodzi wskutek nieuczciwego działania zbywcy.

${ }^{11}$ D. Pardoel: Les conflits de lois en matière de cession de creance. Paris 1997, s. 271-294; C. Walsh: Receivables financing and the conflict of laws: The UNCITRAL Draft Convention on the Assignment of Receivables in International Trade. „Dickinson Law Review" 2001, no. 1, s. 161. 
faktycznego przeniesienia wierzytelności z majątku cedenta na rzecz cesjonariusza (a zatem niezależnie od skuteczności cesji wobec stron tej umowy). W ten sposób, przykładowo, mimo że wierzytelność nie weszła do majatku cesjonariusza, jest on traktowany jako uprawniony, który może skutecznie tym prawem rozporządzać ${ }^{12}$, albo też jego wierzyciele moga uzyskać z niego zaspokojeni $\mathrm{e}^{13}$. Katalog potencjalnych zdarzeń prawnych, od ziszczenia których cesja może wywierać skutek wobec osób trzecich, jest szeroki. Poza przyjęciem prostego założenia, że przelew jest skuteczny erga omnes z chwila, z jaką wywołuje skutki między stronami umowy cesji, prawodawcy moga sięgnąc po inne rozwiązania, takie jak powiązanie skuteczności przeniesienia wierzytelności względem innych podmiotów z chwila: powiadomienia dłużnika o przelewie, dokonania rejestracji cesji w publicznym zbiorze danych czy też ogłoszenia o takim wpisie. Dodatkowo, w celu ochrony masy upadłości cedenta (a zatem zabezpieczenia interesów jego wierzycieli), regulacje prawa upadłościowego wprowadzają mechanizmy prowadzące do ubezskuteczniania czynności uszczuplających majątek upadłego, dokonanych w określonym czasie przed ogłoszeniem upadłości.

Zarysowane wyżej zagadnienie prawne ma swoje implikacje na płaszczyźnie kolizyjnej. W związku z przeciwstawnymi interesami wskazanych podmiotów konieczne staje się prawne unormowanie kwestii skuteczności przelewu wobec osób trzecich. Jednocześnie potrzeba zapewnienia odpowiedniej ochrony zainteresowanym powoduje, że nie zawsze unormowanie to opiera się na zasadzie, zgodnie z która cesja staje się skuteczna erga omens z chwilą skutecznego przejścia wierzytelności z majątku zbywcy na rzecz jej nabywcy. Istnieją bowiem mechanizmy o czym była mowa - pozwalające na uniezależnienie skuteczności przelewu wobec osób trzecich od jej przeniesienia. Możliwe są zatem sytuacje, w których określony podmiot, nawet gdy wierzytelność nie weszła w skład jego majątku, może być traktowany jako uprawniony i skutecznie tym prawem rozporzązacíc ${ }^{14}$.

12 Przykładem takiej sytuacji w prawie polskim może być przypadek skutecznego przeniesienia wierzytelności na rzecz osoby trzeciej przez podmiot, który dokonał jako nabywca - uprzedniej, pozornej czynności prawnej jej nabycia od innego podmiotu. Dokonując tej kolejnej czynności, wskazanemu podmiotowi nie przysługuje przenoszona wierzytelność, gdyż nie nabył jej w związku z nieważnością wcześniejszej pozornej umowy. Mimo to osoba trzecia stanie się wierzycielem (nabędzie wierzytelność), jeżeli dokonała ze zbywca odpłatnej czynności prawnej i działała w dobrej wierze (tak wprost art. $83 \S 2$ polskiego kodeksu cywilnego).

${ }^{13}$ Por. C. Walsh: Receivables financing..., s. 167-169.

${ }^{14}$ G. Cuniber ti: La proposition de règlement de la Commission sur la loi applicable à l'opposabilité des cessions de créances. „Revue critique de droit international privé" $2018, n^{\circ} 4$, s. 796. 
W związku z tym, przy sprzecznych interesach podmiotów występujacych z konkurencyjnymi uprawnieniami do przenoszonej wierzytelności, konieczne staje się wskazanie prawa właściwego do oceny skuteczności przelewu wobec osób trzecich ${ }^{15}$.

\section{Rozstrzygnięcie Trybunału Sprawiedliwości Unii Europejskiej}

Postawione przez Saarländisches Oberlandesgericht cztery pytania prejudycjalne Trybunał Sprawiedliwości Unii Europejskiej zredukował do jednego, zasadniczego - czy art. 14 rozporządzenia Rzym I należy interpretować w ten sposób, że wskazuje on - bezpośrednio względnie przez analogię - prawo właściwe dla kwestii skuteczności wobec osób trzecich przelewu wierzytelności w przypadku wielokrotnego przelewu wierzytelności dokonywanego przez tego samego wierzyciela na rzecz kolejnych cesjonariuszy. Niepotrzebnie przy tym ograniczył się jedynie do tego wąskiego wycinka zagadnienia skuteczności cesji względem osób występujących z konkurencyjnymi uprawnieniami do przenoszonej wierzytelności. Pomimo bowiem tak postawionych pytań prejudycjalnych, w uzasadnieniu do swojego wyroku Trybunał Sprawiedliwości Unii Europejskiej słusznie wskazał na całość problematyki skuteczności przelewu względem osób trzecich i na niej koncentrował swoje rozważania.

Przechodząc do meritum, zarówno wykładnia językowa ${ }^{16}$, jak i historyczna ${ }^{17}$ przepisów rozporządzenia Rzym I skłoniły Trybunał Spra-

${ }_{15}$ W. Kurowski: Nowe kolizyjnoprawne..., s. 146-147; D. Einsele: Die Drittwirkung von Forderungsübertragungen im Kollisionsrecht - ein kritischer Zwischenruf zum Verordnungsvorschlag der Kommission. „Praxis des Internationalen Privat- und Verfahrensrechts" 2019, H. 6, s. 477-478.

${ }_{16}$ Artykuł 14 rozporządzenia Rzym I nie wskazuje prawa właściwego do oceny skuteczności przelewu wierzytelności wobec osób trzecich (tak TSUE w uzasadnieniu wyroku C-548/18, pkt 31); podobnie w pkt. 38 preambuły do tego aktu brak jest wytycznych do obrony tezy o objęciu zakresem rozporządzenia spornej kwestii (tak TSUE w uzasadnieniu wyroku C-548/18, pkt 32). Ponadto art. 27 ust. 2 rozporządzenia zobowiązywał Komisję Europejską do przedłożenia „sprawozdania na temat kwestii skuteczności przelewu lub subrogacji wobec osób trzecich”, a w razie potrzeby „wniosku dotyczącego zmiany [rozporządzenia Rzym I] i oceny wpływu przepisów, które miałyby być wprowadzone (tak TSUE w uzasadnieniu wyroku C-548/18, pkt 34).

${ }^{17} \mathrm{~W}$ art. 13 ust. 3 projektu rozporządzenia Rzym I (wniosku Komisji Europejskiej dotyczącego tego rozporządzenia (COM(2005) 650 wersja ostateczna) kwestię skuteczności przelewu wierzytelności wobec osób trzecich proponowano poddać prawu państwa, w którym cedent ma miejsce zwykłego pobytu w momencie przelewu lub przeniesienia. 
wiedliwości Unii Europejskiej do zajęcia stanowiska, zgodnie z którym w prawodawstwie unijnym brak jest norm kolizyjnych dotyczących wyraźnie kwestii skutków przelewu wierzytelności wobec osób trzecich ${ }^{18}$. Co więcej, luka ta była świadomym wyborem prawodawcy ${ }^{19}$. Pomimo zatem waskiego ujęcia zagadnienia $\mathrm{w}$ pytaniach prejudycjalnych, nie powinno budzić wattpliwości stwierdzenie, że całość szerokiego zagadnienia pierwszeństwa osób występujących z konkurencyjnymi roszczeniami wobec wierzytelności będącej przedmiotem przelewu pozostała poza zakresem unormowania przepisów kolizyjnych ujednoliconych w ramach Unii Europejskiej.

\section{Unormowania kolizyjne skuteczności przelewu wierzytelności wobec osób trzecich w prawodawstwie krajowym oraz propozycja unifikacji}

Z uwagi na brak stosownej regulacji unijnej odnoszącej się do skuteczności cesji wierzytelności względem osób trzecich miarodajnych reguł kolizyjnych należy poszukiwać w prawodawstwie krajowym państw członkowskich. Jednak nie wszędzie odpowiednie przepisy znalazły swoje miejsce w ustawach kolizyjnych, co otwarło drogę dla doktryny lub judykatury, by $\mathrm{w}$ ten sposób wypełnić pozostawiona przez legislację unijną lukę. Z państw, w których omawiane zagadnienie zostało wprost uregulowane, należy wskazać: Belgię, Francję oraz Luksemburg (w tym ostatnim przypadku — jedynie w odniesieniu do przeniesienia wierzy-

Propozycja ta nie została jednak przyjęta w trakcie negocjacji prowadzonych w Radzie Unii Europejskiej (tak TSUE w uzasadnieniu wyroku C-548/18, pkt 33). Warto przypomnieć, że wcześniej wyraźne unormowanie wskazanej problematyki zostało zaproponowane w art. 16 projektu konwencji o prawie właściwym dla zobowiązań umownych i pozaumownych z 1972 r., gdzie zakładano wprost poddanie skuteczności cesji względem osób trzecich prawu przenoszonej wierzytelności. Szerzej o tym projekcie regulacji zob. m.in.: M. Giuliano, in: M. Giuliano, P. Lagarde, Th. van Sasse van Ysselt: Rapport concernant l'avant-projet de convention sur la loi applicable aux obligations contractuelles et non-contractuelles. „Rivista di diritto internazionale privato e processuale” 1973, N 1, s. 246 - 247; L. Collins: Contractual Obligations - The EEC Preliminary Draft Convention on Private International Law. „The International and Comparative Law Quarterly” 1976, vol. 25, s. 56; W. Kurowski: Przelew wierzytelności w prawie prywatnym międzynarodowym. Kraków 2005, s. 59.

18 Tak TSUE w uzasadnieniu wyroku C-548/18, pkt 37.

19 Ibidem. 
telności w ramach sekurytyzacji), gdzie jako właściwe do oceny skutków przelewu wierzytelności wobec osób trzecich uznano prawo miejsca zwykłego pobytu cedenta ${ }^{20}$. Inaczej postapił prawodawca holenderski, poddając skuteczność przelewu erga omnes prawu właściwemu dla umowy zawartej między zbywca a nabywca wierzytelności. W tym przypadku prawo, któremu podlega przelew wierzytelności (wskazane na podstawie art. 14 ust. 1 rozporządzenia Rzym I), będzie także właściwe do oceny skuteczności cesji względem osób trzecich. Bardziej konserwatywną postawą wykazał się prawodawca hiszpański, który omawiane zagadnienie uznał za stosowne poddać prawu właściwemu dla przenoszonej wierzytelności ${ }^{21}$.

Do grona państw, które wypełniły pozostawioną w rozporządzeniu Rzym I lukę w kwestii skuteczności cesji wobec osób trzecich, zaliczyć trzeba także Polskę. Ze względu na reformę polskiego prawa kolizyjnego $^{22}$ i opracowywaną w tamtym czasie ustawę ${ }^{23}$ stało się możliwe uzupełnienie nowej regulacji o art. $36^{24}$. Zgodnie ze wskazanym przepisem, prawo państwa, któremu podlega przelewana wierzytelność, rozstrzyga o skutkach przelewu wobec osób trzecich. Mimo zgłaszanych postulatów ${ }^{25}$, prawodawca nie zdecydował się zatem na bardziej nowoczesne

${ }^{20} \mathrm{O}$ wadach i zaletach tego łącznika w odniesieniu do skuteczności przelewu wobec osób trzecich zob. w szczególności: E.-M. Kieninger: Der Statut der Forderungsabtretung im Verhältnis zu Dritten. „Rabels Zeitschrift für ausländisches und internationales Privatrecht" 1998, Nr. 3, s. 702-710; Eadem: Brussels I, Rome I and questions relating to assignment and subrogation. In: Enforcement of International Contracts in the European Union. Convergence and divergence between Brussels I and Rome I. Eds. J. Meeusen, M. Pertegás, G. Straetmans. Antwerp-Oxford-New York 2004, s. 383-386; W. Kurowski: Przelew wierzytelności..., s. 137-143; P. Lagarde: Retour sur la loi applicable à l'opposabilité des transferts conventionnels de créances. In: Droit et actualité. Etudes offertes à Jacques Béguin. Paris 2005, s. 425-426; A. Wowerka: Prawo właściwe..., s. 148-149, 157; Idem: Przelew wierzytelności.., s. 44-45; W. Kurowski: Kolizyjnoprawna problematyka..., s. 84-87.

${ }^{21}$ G. Cuniberti: La proposition..., s. 793-794.

${ }^{22}$ Zob. projekt ustawy o prawie prywatnym międzynarodowym z dnia 9.10.2006 r., ogłoszony drukiem w „Problemach Prawa Prywatnego Międzynarodowego” 2007, T. 1, s. 115-131; zob. także A. Kozakiewicz, W. Kurowski: Co dalej z kodyfikacja prawa prywatnego międzynarodowego w Polsce? „Kwartalnik Prawa Prywatnego” 2003, z. 4, s. 932-933; W. Kurowski: Przelew wierzytelności..., s. 249—251; M. Pazdan: O projekcie nowej ustawy o prawie prywatnym międzynarodowym. „Problemy Prawa Prywatnego Międzynarodowego" 2007, T. 1, s. 18.

${ }^{23}$ Ustawa z dnia 4 lutego 2011 r. - Prawo prywatne międzynarodowe. T.j. Dz.U. 2015, poz. 1792 [dalej: p.p.m.].

${ }^{24}$ A. Wowerka: Przelew wierzytelności..., s. 59-60; W. Kurowski: Nowe kolizyjnoprawne..., s. 147.

${ }^{25}$ Więcej na ten temat: W. Kurowski: Prawo właściwe..., s. 164-166; Idem, w: „System Prawa Prywatnego”. T. 20B. Red. M. Pazdan. Warszawa 2015, s. 388-392; N. Rycko, w: Prawo prywatne międzynarodowe. Komentarz. Red. J. Poczobut. War- 
i przystające do współczesnego obrotu rozwiązanie, opierające się w omawianym zakresie na łączniku personalnym cedenta.

Przewidziany jako rozwiązanie tymczasowe przepis art. 36 p.p.m. już ponad dziewięć lat stanowi podstawę do wskazania prawa właściwego do rozstrzygania konfliktów między konkurencyjnymi uprawnieniami podmiotów do przenoszonej wierzytelności. Taki stan potrwa z pewnościa dłużej, gdyż dopiero w marcu 2018 r. Komisja Europejska ogłosiła projekt rozporządzenia w sprawie prawa właściwego dla skutków przelewu wierzytelności wobec osób trzecich ${ }^{26}$. Nie będzie ono uzupełniać rozporządzenia Rzym I o kolejne przepisy; zaproponowano bowiem przyjęcie odrębnego, a przy tym rozbudowanego aktu prawnego, poświęconego omawianemu zagadnieniu ${ }^{27}$.

Przy ustalaniu miarodajnego dla skuteczności cesji wobec osób trzecich statutu zastosowanie znajdą trzy łączniki (subiektywny oraz dwa obiektywne), w zależności od tego, o przelew jakiej wierzytelności chodzi. Zgodnie z art. 4 ust. 2 projektu, w przypadku cesji (a) „gotówki złożonej na rachunku w instytucji kredytowej” oraz (b) wierzytelności $\mathrm{z}$ instrumentu finansowego ${ }^{28}$ skutki przelewu wierzytelności wobec osób trzecich podlegać maja prawu właściwemu dla przenoszonej wierzytelności ${ }^{29}$. Z kolei w przypadku cesji dokonywanej w ramach sekurytyzacji jej skuteczność względem osób trzecich podlegać ma prawu miejsca zwykłego pobytu zbywcy ${ }^{30}$, chyba że strony skorzystaja z pozostawionej im przez prawodawcę ograniczonej kolizyjnej autonomii woli i poddadzą tę kwestię prawu właściwemu dla przenoszonych wierzy-

szawa 2017, s. $625-628$.

${ }^{26}$ Projekt rozporządzenia w sprawie prawa właściwego dla skutków przelewu wierzytelności wobec osób trzecich. $\operatorname{COM}(2018) 96$ wersja ostateczna.

${ }^{27} \mathrm{O}$ projekcie rozporzadzenia zob. m.in. A. Dickinson: Tough Assignments: the European Commission's Proposal on the Law Applicable to the Third-Party Effects of Assignments of Claims. „Praxis des Internationalen Privat- und Verfahrensrechts” 2018, H. 4, s. 338-339; W. Kurowski: Kolizyjnoprawna problematyka..., s. 67-90.

${ }^{28}$ Kategoria ta obejmuje wierzytelności wynikające z instrumentów finansowych wskazanych w załączniku do dyrektywy Parlamentu Europejskiego i Rady 2014/65/ UE z dnia 15 maja 2014 r. w sprawie rynków instrumentów finansowych oraz zmieniająca dyrektywę 2002/92/WE i dyrektywę 2011/61/UE. Dz.Urz. UE L nr 173 z dnia 12.06.2014, s. $349-496$.

${ }^{29}$ Zob. też A. Dickinson: Tough Assignments..., s. 339; P. Mankowski: Der Kommissionsvorschlag zum Internationalen Privatrecht der Drittwirkung von Zessionen. „Recht der Internationalen Wirtschaft” 2018, H. 8, s. 495-497; H. Kronke: Assignment of Claims and Proprietary Effects: Overview of Doctrinal Debate and the EU Commission's Proposal. „Oslo Law Review” 2019, no. 1, s. 16; G. Cuniberti: La proposition de règlement..., s. 797; D. Ein sele: Die Drittwirkung..., s. 480.

${ }^{30}$ G. Cuniberti: La proposition de règlement..., s. 798; W. Kurowski: Kolizyjnoprawna problematyka..., s. $79-82$. 
telności ${ }^{31}$. I wreszcie, w każdym innym przypadku, a zatem gdy brak jest podstaw do zastosowania reguł szczególnych wskazanych powyżej, ocena skuteczności przelewu wierzytelności wobec osób trzecich ma być dokonywana na podstawie przepisu ogólnego, posługującego się łącznikiem personalnym zbywcy wierzytelności (miarodajnym w tym zakresie statutem ma bowiem stać się prawo państwa, w którym cedent ma miejsce zwykłego pobytu — art. 4 ust. 1 projektu) ${ }^{32}$.

Projekt rozporządzenia wypełnia lukę w kolizyjnoprawnym unijnym unormowaniu przelewu wierzytelności. Wychodzi także naprzeciw oczekiwaniom wyraźnego uregulowania tej kwestii jednolicie w ramach Unii Europejskiej. Watpliwości rodzi jedynie dopuszczenie przez prawodawce wyjątków od zasady poddania skuteczności cesji wobec osób trzecich prawu państwa, w którym cedent ma miejsce zwykłego pobytu ${ }^{33}$. Na praktyczną ocenę tego rozwiązania przyjdzie jednak jeszcze poczekać.

\section{Bibliografia}

Collins L.: Contractual Obligations - The EEC Preliminary Draft Convention on Private International Law. „The International and Comparative Law Quarterly" 1976, vol. 25.

Cuniberti G.: La proposition de règlement de la Commission sur la loi applicable à l'opposabilité des cessions de créances. „Revue critique de droit international privé" $2018, \mathrm{n}^{\circ} 4$.

Czepelak M.: Międzynarodowe prawo zobowiazań Unii Europejskiej. Komentarz do rozporzadzeń rzymskich. Warszawa 2012.

Dickinson A.: Tough Assignments: the European Commission's Proposal on the Law Applicable to the Third-Party Effects of Assignments of Claims. „Praxis des Internationalen Privat- und Verfahrensrechts” 2018, H. 4.

Einsele D.: Die Drittwirkung von Forderungsübertragungen im Kollisionsrecht - ein kritischer Zwischenruf zum Verordnungsvorschlag der Kommission. „Praxis des Internationalen Privat- und Verfahrensrechts” 2019, H. 6.

Flessner A.: Choice of Law in International Property Law - New Encouragement from Europe. In: Party Autonomy in International Property Law. Eds. R. Westrik, J. van der Weide. Munich 2011.

${ }^{31}$ A. Dickinson: Tough Assignments..., s. 339. Krytycznie propozycję tę ocenia m.in. P. Mankowski: Der Kommissionsvorschlag..., s. 497-499; D. Ein sele: Die Drittwirkung..., s. 480-481.

${ }^{32}$ G. Cuniberti: La proposition de règlement..., s. 794; P. Mankowski: Der Kommissionsvorschlag..., s. 491-494; D. Ein sele: Die Drittwirkung..., s. 479.

${ }^{33}$ W. Kurowski: Kolizyjnoprawna problematyka..., s. 90. 
Flessner A., Verhagen H.L.E.: Assignment in European Private International Law. Claims as property and the European Commission's 'Rome I Proposal'. Munich 2006.

Garcimartín Alférez F.J.: Assignment of claims in the Rome I Regulation: Article 14. In: Rome I Regulation. The Law Applicable to Contractual Obligations in Europe. Eds. F. Ferrari, S. Leible. Munich 2009.

Giuliano M., in: M. Giuliano, P. Lagarde, Th. van Sasse van Ysselt: Rapport concernant l'avant-projet de convention sur la loi applicable aux obligations contractuelles et non-contractuelles. „Rivista di diritto internazionale privato e processuale" $1973, \mathrm{~N}^{\circ} 1$.

Hartley T.C.: Choice of law regarding the voluntary assignment of contractual obligations under the Rome I Regulation. „International and Comparative Law Quaterly” 2011, no. 1.

Kieninger E.-M.: Brussels I, Rome I and questions relating to assignment and subrogation. In: Enforcement of International Contracts in the European Union. Convergence and divergence between Brussels I and Rome I. Eds. J. Meeusen, M. Pertegás, G. Straetmans. Antwerp-Oxford-New York 2004.

Kieninger E.-M.: Der Statut der Forderungsabtretung im Verhältnis zu Dritten. „Rabels Zeitschrift für ausländisches und internationales Privatrecht” 1998, Nr. 3.

Kozakiewicz A., Kurowski W.: Co dalej z kodyfikacja prawa prywatnego międzynarodowego w Polsce? „Kwartalnik Prawa Prywatnego” 2003, z. 4.

Kronke H.: Assignment of Claims and Proprietary Effects: Overview of Doctrinal Debate and the EU Commission's Proposal. „Oslo Law Review” 2019, no. 1.

Kurowski W.: Kolizyjnoprawna problematyka skuteczności przelewu wierzytelności wobec osób trzecich — projekt rozporzadzenia Parlamentu Europejskiego $i$ Rady w sprawie prawa właściwego dla skutków przelewu wierzytelności wobec osób trzecich (COM(2018) 96 final). „Problemy Prawa Prywatnego Międzynarodowego" 2019, T. 25.

Kurowski W.: Nowe kolizyjnoprawne unormowanie podmiotowych zmian stosunku zobowiqzaniowego na tle rozporzadzenia „Rzym I” i polskiej ustawy - Prawo prywatne międzynarodowe z 2011 r. W: Współczesne wyzwania prawa prywatnego międzynarodowego. Red. J. Poc zobut. Warszawa 2013.

Kurowski W.: Prawo właściwe do oceny skuteczności przelewu wierzytelności wobec osób trzecich. W: Znad granicy ponad granicami. Księga dedykowana Profesorowi Dieterowi Martiny. Red. M. Krzymuski, M. Margoński. Warszawa 2014.

Kurowski W.: Przelew wierzytelności $w$ prawie prywatnym międzynarodowym. Kraków 2005.

Kurowski W., w: „System Prawa Prywatnego”. T. 20B. Red. M. Pazdan. Warszawa 2015.

Lagar de P.: Retour sur la loi applicable à l'opposabilité des transferts conventionnels de créances. In: Droit et actualité. Etudes offertes à Jacques Béguin. Paris 2005. 
Leible S., Lehmann M.: Die Verordnung über das auf vertragliche Schuldverhältnisse anzuwendende Recht (,Rom I”). „Recht der Internationalen Wirtschaft" 2008, H. 8.

Mankowski P.: Der Kommissionsvorschlag zum Internationalen Privatrecht der Drittwirkung von Zessionen. „Recht der Internationalen Wirtschaft” 2018, H. 8.

Pardoel D.: Les conflits de lois en matière de cession de créanse. Paris 1997.

Pazdan M.: O projekcie nowej ustawy o prawie prywatnym międzynarodowym. „Problemy Prawa Prywatnego Międzynarodowego" 2007, T. 1.

Rycko N., w: Prawo prywatne międzynarodowe. Komentarz. Red. J. Poczobut. Warszawa 2017.

Verhagen H.L.E., van Dongen S.: Cross-border assignments under Rome I. „Journal of Private International Law” 2010, no. 1.

Walsh C.: Receivables financing and the conflict of laws: The UNCITRAL Draft Convention on the Assignment of Receivables in International Trade. „Dickinson Law Review” 2001, no. 1.

Wowerk a A.: Prawo właściwe dla transakcji faktoringowych. „Problemy Prawa Prywatnego Międzynarodowego" 2009, T. 4.

Wow erk a A.: Przelew wierzytelności w świetle rozporzqdzenia Rzym I. „Problemy Prawa Prywatnego Międzynarodowego" 2011, T. 8.

Zachariasiewicz M.P.: Zmiany w unormowaniu cesji wierzytelności (od artykutu 12 konwencji rzymskiej do artykutu 14 rozporzqdzenia Rzym I). „Problemy Prawa Prywatnego Międzynarodowego" 2010, T. 6. 